\title{
Efficiency of Board Composition on Firm Performance: Empirical Evidence from listed Manufacturing Firms of Bangladesh
}

\author{
Md. Musfiqur Rahman ${ }^{1}$, Farjana Nur Saima ${ }^{2}$
}

Received: February 22, 2018. Revised: March 26, 2018. Accepted: May 5, 2018.

\begin{abstract}
Corporate governance has received massive attention in academic research nowadays due to several recent corporate failures. Inefficiency of corporate governance mechanisms have driven the minds of the researchers and the policy makers to look with more insights into this area. Board composition, as part of corporate governance mechanism, plays a significant role to achieve company's goals or objectives and ensure transparency and accountability. The objective of this study is to find out the efficiency of board composition through board size, independent directors and female directors on firm performance in the listed manufacturing firms of Bangladesh. In this study, a sample of 162 firm years are considered as the sample during the period of 2011 to 2016 . This study finds that large board is the significant explanatory variable in improving firm performance. This study also shows that board independence and female directors have no significant association with firm performance which implies that instrument of corporate governance mechanism particularly board composition is very weak. This study recommends that code of corporate governance, specially the role of independent directors and female directors, should be reformed in the light of cultural and institutional context along with the effective enforcement.
\end{abstract}

Keywords: Corporate governance, Board composition, Independent director, Firm performance, Manufacturing firms, Bangladesh.

JEL Classification Code: G34, L25, M48.

\section{Introduction}

Corporate governance has received massive attention in academic research nowadays due to several corporate failures like Enron, World.com. Inefficiency of corporate governance mechanisms have driven the minds of the researchers and the policy makers to look with more insights into this area. Many corporate governance codes have been developed such as the Sarbanes-Oxley Act in the US, the Organization for Economic Development (OECD) Code, Cadbury Committee report, CLERP 9 in Australia and Combined Code in the UK. Effectiveness of Corporate governance plays a pivotal role in fulfilling the company's objectives or shareholder goals. Corporate governance ensures the better transparency and accountability through the implementation of governance guidelines (Rahman \& Khatun, 2017b).

1 First Author and Corresponding Author. Associate Professor, Dept. of Accounting and Information Systems, University of Dhaka, Bangladesh [Postal Address: Dept. of Accounting and Information Systems, University of Dhaka, Neelkhet Road, Dhaka-1000, Bangladesh]. Email : himukobe@gmail.com

2 MBA Student, Dept. of Accounting \& Information Systems, University of Dhaka.
But prior studies find that failure of corporate governance are occurring frequently and compliance of code of corporate governance is also very low. Rahman and Khatun (2017a) study found that quality of corporate governance is not satisfactory in most of the countries. In Bangladesh, corporate governance guidelines firstly introduced in 2006 and later revised in 2012. The revised corporate governance guidelines incorporated some new issues such as requirements of independent directors, additional statements in the directors report, separation of CEO and CEO, composition of audit committee, role and responsibilities of CEO and CFO, compliance certificate from the professional accountant etc. (Rahman \& Khatun, $2017 b)$. These changes in corporate governance guidelines especially in board structure is to ensure good governance practices, transparency, accountability and improve the firm performance. Prior research documented a mixed result regarding efficiency of board characteristics on firm performance in different country context. But there is lack of research of efficiency of board composition on firm performance after revising the corporate governance guidelines 2012 .

Thus, the objective of this study is to find out the efficiency of board composition on firm performance in the 
listed manufacturing firms of Bangladesh after revising the corporate governance guidelines 2012. In this study, a sample of 162 firm years are considered as the sample during the period of 2011 to 2016. In this study, board composition is examined through board size, board independence and female directors and firm performance is measured by return on asset (ROA).

This study finds that large board is the significant explanatory variable in improving firm performance. This study also shows that board independence and female director have no significant association with firm performance which implies that instrument of corporate governance mechanism particularly board composition is very weak.

This research paper has some contributions, First, This study will help to identify whether the instruments of board composition are effective enough or not. Second, the findings of the study will help the regulator and policymaker to improve the governance mechanism especially the board composition that ultimately improve the firm performance. Finally, this paper will also address the efficiency of the board composition after revising the corporate governance guidelines 2012.

The rest of the paper is organized as follows: section 2 discusses background of CG guidelines and board practices in Bangladesh; section 3 presents literature review and hypothesis development; section 4 discusses the research methodology used in this study. Section 5 shows empirical results including descriptive statistics, correlation matrix and regression analysis, section 6 presents the additional analysis and section 7 ends with discussion and conclusion.

\section{Background of CG Guidelines and Board Practices in Bangladesh}

At present, corporate governance related issues have become a topic of discussion and concern in Bangladesh due to poor corporate performance and different corporate failures. Basically, the Companies Act of 1994, the
Securities and Exchange Rules of 1987, the Banking Companies Act of 1991 are the existing legal framework for corporate governance in Bangladesh. Corporate Governance guidelines are issued by the order and notifications of Bangladesh Securities and Exchange Commission (BSEC). On 20 ${ }^{\text {th }}$ February, 2006 BSEC introduces corporate governance guidelines on "comply or explain" basis to protect the minority shareholder interest and ensure capital market development. If any noncompliance occurs, there should be an explanation for that. Later, on $7^{\text {th }}$ August, 2012 BSEC revised the 2006 guidelines and issues new guidelines 2012 on "comply' basis. A number of changes have been made in respect to board effectiveness, audit committee formulation, role of audit committee, directors' report to shareholder, duties of CEO and CFO and reporting and compliance of corporate governance.

Typically, in Bangladesh, corporate board consists of both executive and non-executive directors except in banking sector. Total board size is within 5 to 20 and the number of independent directors on the board has now been increased from one tenth to one fifth of total number of directors. Also, chairman and CEO position are filled by different persons and it should be mandatorily followed. However, in Bangladesh there are no guidelines or rules regarding female directors especially from family members on the board. Generally, high concentration of ownership and domination by sponsor directors are observed.

\section{Literature Review and Hypothesis Development}

Prior studies documented the mixed evidence between the board characteristics and firm performance. To find out the efficiency of board attributes on firm performance, the variables such as board size, board independence and proportion of female directors on the board are considered. The summary of prior studies are presented in the Table 1.

Table 1. A summary studies on Board composition and firm performance

\begin{tabular}{|l|l|c|l|l|l|l|}
\hline \multicolumn{1}{|c|}{ Study } & \multicolumn{1}{|c|}{ Sample } & $\begin{array}{c}\text { Time } \\
\text { Period }\end{array}$ & \multicolumn{1}{|c|}{ Methods } & $\begin{array}{c}\text { Dependent } \\
\text { Variables }\end{array}$ & Independent Variables & \multicolumn{1}{c|}{ Results } \\
\hline Abdullah (2004) & $\begin{array}{l}\text { KLSE main board } \\
\text { companies }\end{array}$ & $1994-1996$ & t-test & $\begin{array}{l}\text {-ROA } \\
\text {-ROE } \\
\text {-EPS } \\
\text {-Profit Margin }\end{array}$ & $\begin{array}{l}\text {-Board Independence } \\
\text {-CEO duality }\end{array}$ & No relationship \\
\hline $\begin{array}{l}\text { Adams \& } \\
\text { Ferreira (2009) }\end{array}$ & $\begin{array}{l}1939 \text { companies } \\
\text { from S\&P }\end{array}$ & $1996-2003$ & $\begin{array}{l}\text { Fixed effect } \\
\text { Instrumental } \\
\text { variable } \\
\text { approach }\end{array}$ & $\begin{array}{l}\text {-ROA } \\
\text {-Tobin's Q }\end{array}$ & $\begin{array}{l}\text {-Firm Characteristics } \\
\text {-Board Characteristics } \\
\text {-Director Characteristics }\end{array}$ & $\begin{array}{l}\text { Overall gender } \\
\text { diversity on firm } \\
\text { performance is } \\
\text { negative }\end{array}$ \\
\hline
\end{tabular}




\begin{tabular}{|c|c|c|c|c|c|c|}
\hline Study & Sample & $\begin{array}{l}\text { Time } \\
\text { Period }\end{array}$ & Methods & $\begin{array}{c}\text { Dependent } \\
\text { Variables }\end{array}$ & Independent Variables & Results \\
\hline $\begin{array}{l}\text { Ahmed \& Gabor } \\
(2011)\end{array}$ & \begin{tabular}{|l} 
DSE listed 27 \\
banking \\
companies
\end{tabular} & $2003-2008$ & \begin{tabular}{|l}
-OLS \\
-Lag Model
\end{tabular} & \begin{tabular}{|l}
-ROA \\
-ROE \\
-Tobin's Q
\end{tabular} & $\begin{array}{l}\text {-board size } \\
\text {-share of independent } \\
\text { directors } \\
\text {-share of non- } \\
\text { independent non- } \\
\text { executive director } \\
\text {-ownership of directors } \\
\text {-institutional ownership } \\
\text {-general public ownership } \\
\text {-CEO remuneration } \\
\text {-the number of audit } \\
\text { committee meetings }\end{array}$ & $\begin{array}{l}\text {-No impact } \\
\text {-Negative impact or no } \\
\text { impact } \\
\text {-No impact } \\
\text {-No impact } \\
\text {-positive impact or } \\
\text { somewhere no impact } \\
\text {-No impact }\end{array}$ \\
\hline $\begin{array}{l}\text { Baysinger \& } \\
\text { Butler (1985) }\end{array}$ & \begin{tabular}{|l|}
266 major US \\
corps from Forbes
\end{tabular} & $\begin{array}{l}1970 \text { and } \\
1980\end{array}$ & $\begin{array}{l}\text { Simultaneous } \\
\text { equation } \\
\text { regression }\end{array}$ & $\begin{array}{l}\text { Relative return on } \\
\text { equity }\end{array}$ & $\begin{array}{l}\text { Proportion of independent } \\
\text { directors }\end{array}$ & Significantly positive \\
\hline $\begin{array}{l}\text { Bhagat \& Black } \\
(2001)\end{array}$ & \begin{tabular}{|l}
934 large US \\
corporations
\end{tabular} & $1985-1995$ & $\begin{array}{l}\text { OLS and 3SLS } \\
\text { regression }\end{array}$ & $\begin{array}{l}\text {-Tobin's Q } \\
\text {-Operating income } \\
\text { to asset ratio } \\
\text {-Sales to asset } \\
\text { ratio } \\
\text {-stock price return } \\
\text {-Asset growth } \\
\text {-Operating Income } \\
\text { growth } \\
\text {-Sales Growth }\end{array}$ & $\begin{array}{l}\text { Board } \\
\text { independence(proportio } \\
\mathrm{n} \text { of independent } \\
\text { directors minus } \\
\text { proportion of insiders) }\end{array}$ & $\begin{array}{l}\text {-Significantly negative } \\
\text {-significantly negative } \\
\text {-Not significant } \\
\text {-Not significant } \\
\text {-Not significant } \\
\text {-Not significant } \\
\text {-Not significant }\end{array}$ \\
\hline \begin{tabular}{|l} 
Cornett et al., \\
$(2008)$
\end{tabular} & $\begin{array}{l}100 \text { firms of S\&P } \\
\text { Index }\end{array}$ & $1994-2003$ & $\begin{array}{l}\text {-Pooled } \\
\text { regression } \\
\text {-Fama and } \\
\text { Macbath } \\
\text { regression }\end{array}$ & $\begin{array}{l}\text {-Discretionary } \\
\text { accruals } \\
\text {-Adjusted } \\
\text { EBIT/sales }\end{array}$ & $\begin{array}{l}\text {-Proportion of outside } \\
\text { directors } \\
\text {-Lagged CEO duality }\end{array}$ & \begin{tabular}{|l|}
-Significantly negative \\
-Significantly positive \\
-significantly \\
positive(CEOD) \\
Signficantly \\
negative(CEOD) \\
\end{tabular} \\
\hline Costa (2015) & \begin{tabular}{|l}
157 FTSE Small \\
Cap and Fledgling \\
companies
\end{tabular} & 2007-2009 & \begin{tabular}{|l|} 
Quantile \\
regression \\
coupled with \\
OLS and pooled \\
regression
\end{tabular} & ROA & $\begin{array}{l}\text {-Board Size } \\
\text {-Board } \\
\text { Composition(proportion } \\
\text { of outside director) } \\
\text {-CEO duality }\end{array}$ & $\begin{array}{l}\text {-No significant } \\
\text { association } \\
\text {-No significant } \\
\text { association } \\
\text {-Positive impact }\end{array}$ \\
\hline \begin{tabular}{|l} 
Muttakin et al., \\
$(2012)$
\end{tabular} & $\begin{array}{l}\text { 654 DSE listed } \\
\text { firm- year } \\
\text { observations }\end{array}$ & $2005-2009$ & $\begin{array}{l}\text {-OLS } \\
\text {-Instrumental } \\
\text { variable } \\
\text { regression } \\
\text {-FEM }\end{array}$ & $\begin{array}{l}\text {-Tobin's Q } \\
\text {-ROA }\end{array}$ & $\begin{array}{l}\text {-Board Independence } \\
\text {-Board Size } \\
\text {-CEO duality } \\
\text {-Female director } \\
\text {-Foreign director }\end{array}$ & $\begin{array}{l}\text { Positive impact except } \\
\text { CEO duality }\end{array}$ \\
\hline \begin{tabular}{|l|} 
Ramdani, \& \\
Witteloostuijn \\
(2010)
\end{tabular} & $\begin{array}{l}\text { enterprises listed } \\
\text { on the stock } \\
\text { exchanges in four } \\
\text { East Asian } \\
\text { countries - } \\
\text { Indonesia, } \\
\text { Malaysia, South } \\
\text { Korea and } \\
\text { Thailand } \\
\end{array}$ & $2001-2002$ & $\begin{array}{l}\text { Quantile } \\
\text { regression } \\
\text { analysis }\end{array}$ & \begin{tabular}{|l|} 
ROA \\
(average value of \\
return on assets \\
from 2001-2002)
\end{tabular} & $\begin{array}{l}\text {-Proportion of } \\
\text { Independent Director } \\
\text {-CEO duality }\end{array}$ & $\begin{array}{l}\text {-different across the } \\
\text { conditional quantiles } \\
\text { of the distribution of } \\
\text { firm performance }\end{array}$ \\
\hline $\begin{array}{l}\text { Rashid et al., } \\
(2010)\end{array}$ & $\begin{array}{l}90 \text { DSE listed } \\
\text { non-financial firms }\end{array}$ & 2005-2009 & $\begin{array}{l}\text { Linear regression } \\
\text { analysis }\end{array}$ & $\begin{array}{l}\text {-ROA } \\
\text {-Tobin's Q }\end{array}$ & $\begin{array}{l}\text { Board } \\
\text { Composition( Percentag } \\
\text { e of outside } \\
\text { independent directors) }\end{array}$ & \begin{tabular}{|l|} 
outside (independent) \\
directors cannot add \\
potential value to the \\
firm's economic \\
performance \\
\end{tabular} \\
\hline $\begin{array}{l}\text { Rutledge et al., } \\
(2016)\end{array}$ & $\begin{array}{l}\text { NASDAQ-100 } \\
\text { firms over the } \\
\text { period }\end{array}$ & $2010-2014$ & \begin{tabular}{|l}
- Stepwise \\
model for OLS \\
-Treatment effect
\end{tabular} & ROA & $\begin{array}{l}\text {-Proportion of } \\
\text { Independent } \\
\text { Director(PID) }\end{array}$ & \begin{tabular}{|l}
-No significant relation \\
-significant positive \\
relation
\end{tabular} \\
\hline
\end{tabular}




\begin{tabular}{|l|l|l|l|l|l|l|}
\hline \multicolumn{1}{|c|}{ Study } & \multicolumn{1}{|c|}{ Sample } & \multicolumn{1}{c|}{$\begin{array}{c}\text { Time } \\
\text { Period }\end{array}$} & \multicolumn{1}{c|}{ Methods } & $\begin{array}{c}\text { Dependent } \\
\text { Variables }\end{array}$ & Independent Variables & Results \\
\hline & & & $\begin{array}{l}\text { approach to } \\
\text { address } \\
\text { endogenity }\end{array}$ & $\begin{array}{l}\text {-Committee OVERLAP } \\
\text {-Board INTERLOCK } \\
\text {-CEODUAL }\end{array}$ & $\begin{array}{l}\text {-positive relation } \\
\text {-Negative relation }\end{array}$ \\
\hline $\begin{array}{l}\text { Zabri et al., } \\
(2016)\end{array}$ & $\begin{array}{l}\text { Top 100 public } \\
\text { listed companies } \\
\text { in Bursa Malaysia }\end{array}$ & $2008-2012$ & $\begin{array}{l}\text { Spearman's } \\
\text { correlation test }\end{array}$ & $\begin{array}{l}\text {-ROA } \\
\text {-ROE }\end{array}$ & $\begin{array}{l}\text {-Board Size } \\
\text {-Board Independence }\end{array}$ & $\begin{array}{l}\text {-Significant Negative } \\
\text { with ROA } \\
\text {-No relationship }\end{array}$ \\
\hline
\end{tabular}

\subsection{Board Size}

Board size is considered to be an effective tool to control the internal corporate governance of a company. The board of directors holding the top executive position of a company is in charge of setting up policies and strategies and regulating operations of the organizations (Ahmed \& Gabor, 2011). Kiel and Nicholson (2003) found positive impact of board size on firm performance. Large board is equipped with more expertise knowledge and hence can effectively make strong strategic decisions which in turn help the company to maximize its profits. Consistent with the resource dependency theory, larger boards help to reduce uncertainty and improve firm performance as they have more access to external environment (Muttakin et al., 2012). Though large board has more monitoring capabilities and knowledge, some studies argue that large board is not as effective as small one.

Lipton and Lorsch (1992) and Jensen (1993) argued that large work groups create productivity losses because of poor coordination and process problems. Supporting the findings of the positive abnormal stock returns after board size reduction announcement, Yermack (1996) claimed that investors are more responsive to reduction in board size and disapproval of board expansion. On the other hand, some studies find that there is no impact of board size on firm performance. Costa (2015) found no significant result regarding board size and ROA. Similar result is also found by Rouf (2011). However, board size varies among companies around the world due to cultural differences among countries (Zabri et al., 2016). According to Bangladesh corporate governance guidelines 2006 and 2012, the board size should be within 5 to 20 . On the basis of above discussion, the hypothesis is developed as:

$<\mathrm{H} 1>$ There is a positive impact of board size on firm performance in Bangladesh.

\subsection{Board Independence}

The independent directors are appointed to work on behalf of the shareholders interest. It is generally expected that the higher the proportion of independent directors in the board, the higher the transparency of financial reporting and performance of the firm will be. To maximize the shareholder wealth, agency theory suggests to have a large proportion of independent directors on the board to effectively monitor the activities of the managers (Fama \& Jensen, 1983) and to reduce the self-interested behavior of the managers (Muttakin et al., 2012).

Baysinger and Butler (1985) suggest the need for more outside directors and they state that firms with inappropriate board experience poor performance whereas firms with mixed boards structure are able to survive and prosper. In contrast, as supporters of stewardship theory, Donaldson and Davis (1991) conclude that managers should be regarded as steward and hence insider directors help to achieve superior performance. There are mixed evidences regarding the relationship of board independence with firm performance. Cornett et al. (2008) and Rouf (2011) found positive impact of increasing independent directors on firm performance. But prior studies didn't find strong evidence of greater firm performance due to larger board independence (Bhagat \& Black, 2001; Costa, 2015; Rutledge, Karim, \& Lu, 2016).

According to Bangladesh corporate governance guidelines 2006 the proportion of independent directors should be at least one tenth of total directors on the board and later in 2012 the proportion has been increased to one fifth of total Board of directors. That means the regulatory body is recognizing the need for independent directors as they have the capability to protect the minority interest in Bangladesh, a country with family dominated firm and poor regulatory oversight body (Muttakin et al., 2012). On the other hand, Rashid et al. (2010) claim that introducing independent directors in Bangladesh may increase transparency but due to institutional and cultural differences it may not result in firm value addition. Ahmed and Gabor (2011) also argue that independent directors just do the supervision and should not guarantee earning profit. Thus the hypothesis is as follows:

$<\mathrm{H} 2>$ There is a no impact of board independence on firm performance in Bangladesh.

\subsection{Female Directors}

Women are now participating and contributing in every sector of the economy in Bangladesh. In corporate sector 
they are playing a big role either as entrepreneurs or members of board of directors and effectively ensuring corporate governance of corporations. Generally females are perceived to have patience, sincerity, greater managing and decision making ability by looking into details than their male counterparts. Thus they facilitate the governing process of a firm. Muttakin et al. (2012) also find positive association of female directors on firm performance in Bangladesh. Adams and Ferreira (2009) find that female directors' attendance is greater than the male ones and due to females' monitoring on the board male directors attendance problems become less and also poor performing CEOs are held accountable. However, they find a negative impact of gender diversity on firm value. It is really necessary to consider cultural and organizational context in studying female directors' role in increasing firm performance.

Most of the firms, especially the manufacturing ones in Bangladesh are family ownership concentrated. Muttakin et al. (2012) pointed out that in Bangladeshi family firms, female directors are generally wives and daughters of sponsors and managing directors and they are appointed on the basis of family ties, irrespective of their business skills and educational background. Rahman (2016) stated that female directors are appointed by the controlling shareholders and controlling shareholders control everything according to their own way and female directors have no voice or remain silent in the board meeting. As our sample of this study consists of manufacturing firms and the arguments given above, the hypothesis is developed as:

$<\mathrm{H} 3>$ There is no impact of proportion of female directors on firm performance of Bangladesh.

\section{Research Methodology}

\subsection{Sample and Data source}

To find out the impact of board characteristics on firm performance, a random sample of 27 firms during 20112016 has been taken from listed manufacturing Companies in DSE. So the data set consist of total 162 firm- year observations. The sample firms have been taken from textile Engineering, Chemical, Paper and printing, tannery and food sectors. Initially, the plan was to collect data of all firms of those above sectors mentioned. But finally most of the firms have to be excluded due to several reasons. One reason is that maximum firms have changed their reporting year during the sample period and so annual reports are not available for all 6 years. Secondly, some firms have annual reports but only the audited financial statements and corporate governance related information is missing there. Thirdly, as most of the firms are newly listed in DSE, prior year information is not available for those firms. Finally, we ended up with 162 firm-year observations. Annual reports are downloaded from the respective firms' website. Some firms have kept only recent 3 to 4 years annual report in their website. In that case annual reports have been collected from website of Lanka Bangla Financial Portal. Corporate governance related data i.e. board characteristics information and other variables information are hand collected from corporate governance report, profit and loss account, balance sheet, notes to the financial statements or any other part of the published annual reports of the firms.

\subsection{Research Model}

A multivariate regression model is applied to test the hypotheses following the methodology used by Ahmed and Gabor (2011) and Muttakin et al. (2012).

Firm Performance $=\beta 0+\beta 1$ LNBSIZE $+\beta 2$ BIND $+\beta 3$ FEMD $+\beta 4$ LNFSIZE $+\beta 5$ LNAGE $+\beta 6$ LEV $+\varepsilon$

In this study, ROA, a proxy measure of firm performance, has been taken as dependent variable. Many prior studies (Ramdani \& Witteloostuijn, 2010; Rashid et al., 2010; Muttakin et al., 2012; Rutledge et al., 2016; Zabri, Ahmad, \& Wah, 2016) used ROA as a measure of firm performance. Following the works of Adams and Ferreira (2009), Rashid et al. (2010), Ahmed and Gabor (2011), Muttakin et al. (2012) and Zabri et al. (2016), board size, board independence, and percentage of female directors have been used as board characteristics measures i.e. independent variables of this study. At first, CEO duality is also included in the board characteristics variables. But later it has to be excluded this variable as CEO duality does not exist in any firms except 3 firms in the sample taken. Those 3 firms also have separated CEO and Chairman Position after 2012.So, it can be said that there is no existence of CEO duality in Bangladeshi manufacturing firms right now. The impact of board characteristics on firm performance has been determined by controlling for firm size, age, and leverage ratio.

Here, the definition of the research model is explained below:

\begin{tabular}{|ll|}
\hline Firm Performance & $\begin{array}{l}\text { Measured by ROA (Net profit after tax divided } \\
\text { by total assets) }\end{array}$ \\
\hline LNBSIZE & $\begin{array}{l}\text { Natural logarithm form of total board size (measured as } \\
\text { total number of directors on board) }\end{array}$ \\
\hline BIND & $\begin{array}{l}\text { Proportion of independent directors (measured as the } \\
\text { percentage of independent directors to total board size) }\end{array}$ \\
\hline
\end{tabular}




\begin{tabular}{|ll|}
\hline FEMD & $\begin{array}{l}\text { Proportion of female directors (measured as percentage } \\
\text { of female directors to total board size) }\end{array}$ \\
\hline LNFSIZE & $\begin{array}{l}\text { Natural logarithm form of firm size (measured as total } \\
\text { sales revenue of the firms) }\end{array}$ \\
\hline LNAGE & $\begin{array}{l}\text { Natural logarithm form of total firm age (measured as age } \\
\text { of firm from the incorporation date to sample year period) }\end{array}$ \\
\hline LEV & $\begin{array}{l}\text { Firm Financial leverage (measured as total debt divided } \\
\text { by total assets) }\end{array}$ \\
\hline
\end{tabular}

At first, pooled OLS regression is applied. One potential problem with OLS method is that it doesn't take into account for endogeneity problem arisen in corporate governance research and hence produces biased results (Ahmed \& Gabor, 2011). Researchers use several methods to resolve the endogeneity problem. Following Ahmed and Gabor (2011), lag model has also been used to resolve endogeneity problem in the analysis and hence lagged dependent variable is considered in the respective model. Heteroskedascity test has also been conducted using Busch-Pagan test to check whether any heteroskedasticity problem exists and White's (1980) heteroskedasticity consistent-error adjustment has been applied to remove the problem. Moreover, as there may be firm specific heterogeneity (unobserved fixed effects) in the data set, fixed or random effect model is also used based on the Hausman test analysis.

\section{Empirical Results}

\subsection{Descriptive Statistics}

Table 2 represents results of descriptive analysis regarding the dependent and independent variables used in this study. This table shows mean, median, minimum, maximum, and standard deviation of the observed values for the year 2011-2016 i.e. total 162 firm years. Total board size (BSIZE) and firm age (FAGE) are expressed in actual value in the table. Also, BIND, FEMD, leverage (LEV) and ROA are expressed in percentage and firm size (FSIZE) is in logarithm form. The mean board size is 6 ranging from 3 to 11 with a standard deviation of 1.627 .

According to corporate governance guidelines 2012 board size ranges from 5 to 20 but results of the table shows a violation of this rule. Later, observing the whole data set it has been found that actually one firm in 2011 has a board size of 3 members but after that it increased the number of board members. That's the reason the minimum number is less than 5 . On an average $21.80 \%$ of total board directors is independent directors meaning that requirement of keeping at least $20 \%$ independent directors has been complied by maximum firms in Bangladesh. The number of female directors is almost same as independent directors but the maximum percentage of female directors is $80 \%$ meaning increased number of female participation. The average firm size is 21.061 implying average firm sales of BDT 4150.68 million. The mean firm age is 31 years ranging from minimum 31 years to maximum 67 years. The debt to total asset ratio (LEV) is $53 \%$ ranging from $15 \%$ to $532.20 \%$ with standard deviation of $44 \%$. The average firm performance measured by ROA is $9.67 \%$ ranging from negative $3 \%$ to positive $262 \%$.

Table 2. Descriptive Statistics

\begin{tabular}{|c|c|c|c|c|c|c|}
\hline Variable & Obs. & Mean & Min & Median & Max & Std. Dev. \\
\hline BSIZE & 162 & 6 & 3 & 6 & 11 & 1.627 \\
\hline BIND(\%) & 162 & 21.80 & 0 & 20.00 & 43.00 & 8.90 \\
\hline FEMD(\%) & 162 & 18.90 & 0 & 20.00 & 80.00 & 15.40 \\
\hline FSIZE(In) & 162 & 21.061 & 14.73 & 21.23 & 24.5 & 1.679 \\
\hline FAGE & 162 & 31 & 10 & 31 & 67 & 13.513 \\
\hline LEV & 162 & 53.00 & 15.00 & 51.00 & 532.2 & 44.00 \\
\hline ROA & 162 & 9.67 & -3.00 & 4.1 & 262.2 & 26.9 \\
\hline
\end{tabular}

\subsection{Correlation Matrix}

Table 3 represents Pearson correlation matrix between dependent and independent variables. The correlation matrix shows that board size (0.155) and board independence (0.088) are positively associated with firm performance ROA but female directors (-0.056) are negatively associated with firm performance.

Table 3. Correlation Matrix

\begin{tabular}{|c|c|c|c|c|c|c|c|}
\hline & ROA & LNBSIZE & BIND & FEMD & LNFSIZE & LNAGE & LEV \\
\hline ROA & 1.000 & & & & & & \\
\hline LNBSIZE & 0.155 & 1.000 & & & & & \\
\hline BIND & 0.088 & -0.090 & 1.000 & & & & \\
\hline FEMD & -0.056 & -0.151 & -0.056 & 1.000 & & & \\
\hline LNFSIZE & 0.178 & 0.128 & 0.148 & -0.195 & 1.000 & & \\
\hline LNAGE & 0.133 & 0.085 & 0.105 & -0.192 & 0.228 & 1.000 & \\
\hline LEV & -0.005 & -0.125 & 0.056 & -0.087 & 0.022 & -0.058 & 1.000 \\
\hline
\end{tabular}

In order to test whether there is any multicollinearity problem additionally VIF test has been conducted. The result also reveals there's no severe multicollnearity as the mean VIF value is less than 10 (Gujarati, 2003). 
Table 4. Checking of Multicollinearity

\begin{tabular}{|c|c|c|}
\hline Variable & VIF & $\mathbf{1 / V I F}$ \\
\hline LNBSIZE & 1.07 & 0.935323 \\
\hline BIND & 1.04 & 0.957163 \\
\hline FEMD & 1.10 & 0.912549 \\
\hline LNFSIZE & 1.11 & 0.898958 \\
\hline LNAGE & 1.10 & 0.91306 \\
\hline LEV & 1.04 & 0.965334 \\
\hline Mean VIF & 1.08 & \\
\hline
\end{tabular}

\subsection{Regression Results}

Table 5 represents the regression results of board characteristics on firm performance. According to the results board size is significantly and positively related with firm performance in the three regressions. So accounting measure of firm performance is highly influenced by the larger board size. In context of Bangladesh, larger board helps to monitor management activity and have access to external network for financing thereby contributing to firm value maximization. The result is in line with the findings of Muttakin et al. (2012) and Johl et al. (2015) studies. The conclusion above supports the resource dependency theory that board size has positive effect on firm value and thus our hypothesis $\mathrm{H} 1$ is accepted.

On the other hand, there is insignificant relationship of board independence and proportion of female directors with ROA in each of the regression. Board independence and female directorship cannot add value to the firm performance measure. Other studies such as Abdhullah (2004), Rashid et al. (2010), Ahmed and Gabor (2011), Costa (2015), Johl et al. (2015) and Zabri et al. (2016) also found no significant association of board independence with firm performance. The result implies that independent directors are not playing their monitoring role or their role is significant only to ensure transparency and disclosure of corporate activities not to increase firm value. It can also be inferred that independent directors is not concerned about corporate performance since they only get some meeting fee as compensation which is not very much linked to the firm performance. In case of female directorship, it can be concluded that most manufacturing firms in Bangladesh are family owned business and female directors in those firms are assigned based on family relationship. Thus, they are only for ownership of shares and actually add no value to firm performance. So, our hypotheses $\mathrm{H} 2$ and $\mathrm{H} 3$ are also accepted.

Table 5 also shows significant impact of control variableleverage on firm performance. Leverage is positively associated with ROA and it's consistent with Muttakin et al. (2012). Firm size is significant at $10 \%$ and positively associated with ROA in regression using Pooled OLS model but is insignificant in other regressions model. Firm age is negatively and insignificantly associated with firm performance in each regression.

Table 5. Board characteristics and firm performance

\begin{tabular}{|c|c|c|c|}
\hline & \multicolumn{3}{|c|}{ Dependent Variable: ROA } \\
\hline & Pooled OLS & Lag Model & Random Effect \\
\hline Constant & $\begin{array}{c}-0.8202386 \\
(0.037)\end{array}$ & $\begin{array}{c}-0.8168645^{*} \\
(0.074)\end{array}$ & $\begin{array}{c}-0.6697748 \\
(0.062)\end{array}$ \\
\hline LAGROA & - & $\begin{array}{c}0.1728283^{*} \\
(0.094)\end{array}$ & - \\
\hline LNBSIZE & $\begin{array}{c}0.1888492 \\
(0.001)\end{array}$ & $\begin{array}{c}0.1763219 \\
(0.003)\end{array}$ & $\begin{array}{c}0.1001344 \\
(0.243)\end{array}$ \\
\hline BIND & $\begin{array}{c}0.2114911 \\
(0.135)\end{array}$ & $\begin{array}{c}0.1761087 \\
(0.285)\end{array}$ & $\begin{array}{c}0.1303515 \\
(0.506)\end{array}$ \\
\hline FEMD & $\begin{array}{c}0.0230466 \\
(0.899)\end{array}$ & $\begin{array}{c}0.0858183 \\
(0.720)\end{array}$ & $\begin{array}{c}0.1105019 \\
(0.451)\end{array}$ \\
\hline LNFSIZE & $\begin{array}{c}0.0218413^{*} \\
(0.077)\end{array}$ & $\begin{array}{c}0.0230279 \\
(0.134)\end{array}$ & $\begin{array}{c}0.0223416 \\
(0.120)\end{array}$ \\
\hline LNAGE & $\begin{array}{c}-0.0428845 \\
(0.226)\end{array}$ & $\begin{array}{c}-0.0531749 \\
(0.183)\end{array}$ & $\begin{array}{c}-0.0447054 \\
(0.466)\end{array}$ \\
\hline LEV & $\begin{array}{c}0.3856907^{*+1 *} \\
(0.001)\end{array}$ & $\begin{array}{c}0.3979833^{\text {nat }} \\
(0.000)\end{array}$ & $\begin{array}{c}0.4027847^{* * * *} \\
(0.000)\end{array}$ \\
\hline $\mathrm{R}^{2}$ & 0.4369 & 0.4764 & 0.4258 \\
\hline
\end{tabular}

Table- 5 shows results of Pooled OLS model, Lag Model, and Random Effect model. Based on the hausman test, random effects model is chosen instead of fixed effect. The standard error and $t$ statistics are calculated using white's(1980) heteroskedasticity-consistent error and only probability is presented in the parentheses ${ }^{* * *}$ significance at $1 \%$ level, ${ }^{* *}$ significance at $5 \%$ level, * significance at $10 \%$ level).

\section{Additional Analysis}

Corporate governance guidelines in Bangladesh have been issued first 2006 and later revised in 2012. As a result there are some changes made. Increasing the number of independent directors is one of them. As the data has been collected from 2011-2016, there may be an effect of 2011 board structures data on the regression result. In order to check the robustness of the results, year dummy has also been incorporated in the three models to find out whether there is any impact of previous year effect. All the results are consistent with the previous results except the pooled OLS model where board independence is positively associated with firm performance and is significant at $5 \%$ level. So there may be an effect of increase in independent director's requirement on firm performance. 
Table 6. Regression results considering the time dummy

\begin{tabular}{|c|c|c|c|}
\hline & Pooled OLS & Lag Model & RE \\
\hline Constant & $\begin{array}{c}-0.8417949 \\
(0.031)\end{array}$ & $\begin{array}{c}-0.809756 \\
(0.073)\end{array}$ & $\begin{array}{c}-0.707791 \\
(0.054)\end{array}$ \\
\hline LAGROA & - & $\begin{array}{c}0.1766513 \\
(0.090)\end{array}$ & - \\
\hline LNBSIZE & $\begin{array}{c}0.1985685 \\
(0.001)\end{array}$ & $\begin{array}{r}0.183234 \\
(0.004)\end{array}$ & $\begin{array}{c}0.1148757 \\
(0.187)\end{array}$ \\
\hline BIND & $\begin{array}{c}0.2954931 " \\
(0.031)\end{array}$ & $\begin{array}{c}0.2203916 \\
(0.178)\end{array}$ & $\begin{array}{c}0.2165671 \\
(0.330)\end{array}$ \\
\hline FEMD & $\begin{array}{c}0.0290337 \\
(0.875)\end{array}$ & $\begin{array}{c}0.0898623 \\
(0.714)\end{array}$ & $\begin{array}{c}0.1057747 \\
(0.480)\end{array}$ \\
\hline LNFSIZE & $\begin{array}{c}0.0220639 \\
(0.081)\end{array}$ & $\begin{array}{c}0.0230355 \\
(0.143)\end{array}$ & $\begin{array}{c}0.0222144 \\
(0.128)\end{array}$ \\
\hline LNAGE & $\begin{array}{c}-0.0405015 \\
(0.262)\end{array}$ & $\begin{array}{c}-0.0544436 \\
(0.192)\end{array}$ & $\begin{array}{c}-0.0394775 \\
(0.533)\end{array}$ \\
\hline LEV & $\begin{array}{c}0.3800795 \\
(0.001)\end{array}$ & $\begin{array}{c}0.3925271 \\
(0.001)\end{array}$ & $\begin{array}{c}0.3965245 \\
(0.000)\end{array}$ \\
\hline$R^{2}$ & 0.4458 & 0.4841 & 0.4368 \\
\hline rear Dummy & yes & yes & yes a \\
\hline
\end{tabular}

\section{Discussion and Conclusion}

Corporate board structure works as an internal corporate governance mechanism. If the board is not effective in maintaining its role properly, whole governance system may collapse. The regulatory body tries to ensure the board effectiveness by incorporating standard set of codes practiced by developed countries. But compliance with the corporate governance guidelines and its effectiveness to maximize firm performance depends on the cultural and institutional factors of a particular country also. So, major objective of this paper is to investigate whether there is any impact of board characteristics on firm performance in Bangladesh. In order to find out the relationship of board characteristics with firm performance, a sample of 162 firmyear observations of DSE listed manufacturing firms has been taken.

The study reveals that larger board size contributes to improving firm performance. This result is line with the findings of Muttakin et al. (2012) and Johl et al. (2015). Consistent with the findings of Abdhullah (2004), Rashid et al. (2010), Ahmed and Gabor (2011), Costa (2015), Johl et al. (2015) and Zabri et al. (2016), this study also reveals an insignificant impact of another board characteristic-board independence on firm performance. It implies that increasing number of independent directors does not necessarily result in higher firm performance rather increased board independence contributes to more transparency and disclosure practices of the firms. It can also be argued that increasing board independence as a code of conduct will not add value in case of Bangladesh unless their role is monitored properly. Finally, the study has found female directorship having insignificant impact on firm performance-ROA, implying that female directors are just for holding ownership in most of the family firms so that family owners play a dominant role. In context of Bangladesh culture, as most female directors have family ties with sponsor directors of the firms, they are appointed regardless of their skills in business profession and so they play inactive roles unlike those in the developed countries.

In short, the empirical results shows that large board is the significant explanatory variable in improving firm performance. This study also shows that board independence and female director have no significant association with firm performance which implies that instrument of corporate governance mechanism particularly board composition is very weak.

This study will help the regulators to look into more insight in the corporate governance related issues and reform the codes of standard practices in light of the cultural context of Bangladesh. Introducing the guidelines alone cannot help to improve performance and protect minority interest without effective execution of those rules. A way to maintain the balance properly should be sought out. Thus, this study recommends that code of corporate governance, specially the role of independent director and female directors, should be reformed in the light of cultural and institutional context along with the effective enforcement. However, this study indicates future area of research which can be done by considering large sample size, ownership structures (institutional ownership, director ownership, govt. ownership) and internal and external firm performance.

\section{References}

Abdullah, S. N. (2004). Board composition, CEO duality and performance among Malaysian listed Companies. Corporate Governance: The International Journal of Business in Society, 4(4), 47-61. https://doi.org/10.1108/14720700410558871

Adams, R. B., \& Ferreira, D. (2009). Women in the boardroom and their impact on governance and performance. Journal of Financial Economics, 94(2), 291-309. https://doi.org/10.1016/j.jfineco.2008.10.007.

Ahmed, H., \& Gábor, A. (2011). An examination of the relationship of governance structure and performance: Evidence from banking companies in Bangladesh. Society and Economy, 34(4), 643-666.

Black, B. S., \& Bhagat, S. (2002). The non-correlation between board independence and long-term firm 
performance. Journal of Corporation Law, 27, 231273.

Baysinger, B. D., \& Butler, H. N. (1985). Corporate governance and the board of directors: Performance effects of changes in board composition. Journal of Law, Economics \& Organization, 1(1), 101-124.

Cornett, M. M., Marcus, A. J., \& Tehranian, H. (2008). Corporate governance and pay-for-performance: The impact of earnings management. Journal of Financial Economics, 87(2), 357-373.

Costa, M. D. (2015). Impact of CEO Duality and Board Independence on FTSE Small Cap \& Fledgling Company Performance. World Review of Business Research, 5(1), 1-19.

Donaldson, L., \& Davis, J. H. (1991). Stewardship Theory or Agency Theory: CEO Governance and Shareholder Returns, Australian Journal of Management, 16(1), 49-64.

Fama, E. F., \& Jensen, M. C. (1983). Separation of ownership and control. Journal of Law and Economics, 26(2), 301-25

Gujarati, D. (2003). Basic Econometrics, 4th Ed, New York, McGraw-Hill.

Jensen, M. C. (1993). The modern industrial revolution, exit, and the failure of internal control systems. The Journal of Finance, 48(3), 831-880. https://doi.org/10.1111/j.1540-6261.1993.tb04022.x

Johl, S. K., Kaur, S., \& Cooper, B. J. (2015). Board Characteristics and Firm Performance: Evidence from Malaysian Public Listed Firms. Journal of Economics, Business and Management, 3(2), 239243.

Kiel, G. C., \& Nicholson, G. J. (2003). Board Composition and Corporate Performance: How the Australian experience informs contrasting theories of corporate governance. Corporate Governance: The International Journal of Business in Society, 11(3), 189-205.

Lipton, M., \& Lorsch, J. W. (1992). A modest proposal for improved corporate governance. Business Lawyer, 48, 59-77.

Muttakin, M .B., Khan, A., \& Subramaniam, N. (2012). Board structure and firm performance: Evidence from an emerging economy. AT Business Management Review. 8(2), 97-108.

Rahman, M. M. (2016). Determinants of CEO compensation: An empirical evidence from listed banks of
Bangladesh. Journal of Business Studies. 1, 127-161. http://www.rieb.kobe-u.ac.jp/tjar/conference/7th/CC2 MD\%20MusfiqurRAHMAN.pdf

Rahman, M. M., \& Khatun, N. (2017a). Quality of Corporate Governance: A Review from the Literature. The Journal of Asian Finance, Economics and Business, 4(1), 59-66. http://dx.doi.org/10.13106/jafeb.2017.vol4.no1.59

Rahman, M. M., \& Khatun, N. (2017b). A Comparative Analysis of Corporate Governance Guidelines: Bangladesh Perspective. The East Asian Journal of Business Management, 7(2), 5-16. https://doi.org/10.13106/eajbm.2017.vol7.no2.5

Ramdani, D., \& Witteloostuijn, A. V. (2010). The Impact of Board Independence and CEO Duality on Firm Performance: A Quantile Regression Analysis for Indonesia, Malaysia, South Korea and Thailand. British Journal of Management, 21(3), 607-627.

Rashid, A., de Zoysa, A., Lodh, S., \& Rudkin, K. (2010). Board composition and firm performance: Evidence from Bangladesh. Australasian Accounting Business \& Finance Journal, 4(1), 76-95. http://ro.uow.edu.au /aabfj/vol4/iss $1 / 5 /$

Rutledge, R. W., Karim, K. E., \& Lu, S. (2016). The effects of board independence and CEO duality on firm performance: evidence from the NASDAQ-100 index with controls for endogeneity. Journal of Applied Business and Economics, 18(2), 49-71. http://www.na-businesspress.com/JABE/Rutledge RW_Web18_2_.pdf

Rouf, M. A. (2011). The Relationship between Corporate Governance and Value of the Firm in Developing Countries: Evidence from Bangladesh. The International Journal of Applied Economics and Finance, 5(3), 237-244.

Yermack, D. (1996). Higher market valuation of companies with a small board of directors. Journal of Financial Economics, 40(2), 185-211.

Zabri, S. M., Ahmad, K., \& Wah, K. K. (2016). Corporate Governance Practices and Firm Performance: Evidence from Top 100 Public Listed Companies in Malaysia. Procedia Economics and Finance, 35, 287-296.

White, H. (1980). A heteroskedasticity-consistent covariance matrix estimator and a direct test for heteroskedasticity. Econometrica, 48(4), 817-838. 